\title{
Evidence Based Library and Information Practice
}

\author{
News/Announcements
}

Announcing ISHIMR 2015!

(a) 2014. This is an Open Access article distributed under the terms of the Creative Commons-AttributionNoncommercial-Share Alike License 4.0 International (http://creativecommons.org/licenses/by-nc-sa/4.0/), which permits unrestricted use, distribution, and reproduction in any medium, provided the original work is properly attributed, not used for commercial purposes, and, if transformed, the resulting work is redistributed under the same or similar license to this one.

The organizing committee of the ISHIMR 2015 Committee are pleased to announce the $17^{\text {th }}$ International Symposium for Health Information Management Research (ISHIMR), which will take place on 25-26 June 2015, at York St John University, in York, England, UK. ISHIMR 2015 is a collaboration between York St John University and the University of Sheffield.

ISHIMR 2015 will bring together researchers and professionals in the general area of ehealth, health information management and librarianship, and health informatics and will provide a forum for the presentation and discussion of their research activities.

ISHIMR 2015 will feature oral and poster presentations and a doctoral symposium. We are also delighted to announce that our keynote speakers will be Professor Frances Mair from the University of Glasgow, and Dr Andrew Booth from ScHARR at the University of Sheffield. ISHIMR 2015 will include a multidisciplinary audience and the opportunity for discussions and research collaborations between academia, government and industry.
Please see the ISHIMR 2015 web-site (www.ishimr2015.com) for a list of themes and topics the conference covers.

We invite you to consider submitting your research contributions or practical experience reports to the conference when the $1^{\text {st }}$ call for papers is made in September 2014. All papers will be blind peer-reviewed by at least two members of the Programme Committee. The deadline for submission of papers and poster abstracts is: 15 ${ }^{\text {th }}$ January 2015.

All papers presented and abstracts for posters will be published in the Conference Proceedings. We expect the best papers to be published in a special issue of an international journal.

Please circulate this announcement to your colleagues and fellow researchers. Further information about ISHIMR 2015 is available at www.ishimr2015.com.

On behalf of the organising committee, we look forward to seeing you at ISHIMR 2015.

Dr. Hannah Spring
Dr. Barbara Sen
Professor Peter Bath
(Conference Chairs) 